\title{
THE VARIED PRESENTATIONS OF MECKEL'S DIVERTICULUM IN PEDIATRIC AGE GROUP IN A TERTIARY CARE CENTRE
}

\author{
Ramesh B. Hatti ${ }^{1}$, Mohammed. M. Pasha ${ }^{2}$
}

\section{HOW TO CITE THIS ARTICLE:}

Ramesh B. Hatti, Mohammed. M. Pasha. "The Varied Presentations of Meckel's Diverticulum in Pediatric Age Group in a Tertiary Care Centre". Journal of Evolution of Medical and Dental Sciences 2014; Vol. 3, Issue 08, February 24; Page: 1928-1933, DOI: 10.14260/jemds/2014/2082

ABSTRACT: BACKGROUND: Although Meckel's diverticulum is the most prevalent congenital abnormality of the gastrointestinal tract; it has varied presentations and often becomes a diagnostic challenge. PATIENTS AND METHODS: This was a retrospective study of all children who had underwent surgery for Meckel's Diverticulum in the department of Pediatric Surgery, S. Nijalingappa Medical college and H.S.K Hospital, Bagalkot between February 2009 and February2013. RESULT: A total of 17 patients (10male and 7 female) aged from 1month to 13 years with a diagnosis of Meckel's Diverticulum were evaluated and analyzed, looking at age, gender, clinical features, investigations, histopathological findings and surgical interventions. All patients were symptomatic and presented with various clinical features like intestinal obstruction(29.4\%), perforated Meckel's Diverticulum(23.5\%), diverticulitis(17\%), intussusceptions(11.7\%), patent vitellointestinal duct

( Meckel's prolapse) (11.7\%), Littre's hernia(5.8\%). All the cases were investigated and underwent surgical intervention Meckel's diverticulectomy/ resection anastomosis and were followed up. Most common post-operative complication was wound infection. CONCLUSION: A Preoperative diagnosis of complicated Meckel's Diverticulum may be challenging because of the overlapping clinical and imaging features of the other acute surgical and inflammatory conditions of the abdomen, hence it is necessary to maintain a high incidence of suspicious in the pediatric age group.

KEYWORDS: Meckel's Diverticulum; Meckel's scan; Pediatric; Bleeding P/R; Intussusception; Littre's hernia.

INTRODUCTION: Meckel's diverticulum (MD) is one of the most common congenital abnormalities of the gastrointestinal tract, occurring in approximately $2 \%$ of the population. Nearly two centuries have passed since its first description by Johan Friederich Meckel. Meckel's diverticulum is a true intestinal diverticulum that results from the failure of the vitelline duct to obliterate during the fifth week of fetal development. ${ }^{1}$ It contains all normal layers of the intestinal wall and, in approximately 50 percent of cases, contains tissue from other sites (ectopic tissue), 60-85\% of which is gastric mucosa and $5-16 \%$ pancreatic tissue. ${ }^{2}$ In the majority of cases, it is asymptomatic. However, it is prone to complications, especially in children, due to ectopic epithelial lining and various bands, reflective of its embryological development. Although the lifetime risk of a Meckel's diverticular complication varies from 4 to $34 \%$, more than 50 to $60 \%$ of the patients who develop symptoms are younger than 2 years of age. ${ }^{3}$ Harper et al. suggested that a bleeding MD should be identifiable scintigraphically using $99 \mathrm{mTc}$ pertechnetate, since it is concentrated by gastric mucosa. ${ }^{4}$ The Tc99 Meckel's scan has a reported sensitivity of 81 to $90 \% .^{5}$ The purpose of this study was to review the various presentations of Meckel's diverticulum, to estimate the epidemiologic features and the extent of this clinical entity at our center and to review the detection techniques and treatment options. 


\section{ORIGINAL ARTICLE}

MATERIALS AND METHODS: The records of all children who underwent surgery for Meckel's Diverticulum in the department of Pediatric Surgery of the S. Nijalingappa Medical college and H.S.K hospital, Bagalkot between February 2009 to February 2013 were reviewed. They were analyzed with respect to their age at presentation, gender, clinical features, histopathological findings, investigations and surgical interventions performed.

RESULTS: During the above period, 17 children were found to have symptomatic Meckel's Diverticulum. The youngest child was 1 month old, whereas the oldest was 13 years. There were 10 males and 07 females, giving a male to female ratio of 1.4: 1.11 patients presented to casualty as an acute emergency. Of them 5 presented with bilious vomiting, abdominal distension and absolute constipation, features suggestive of acute intestinal obstruction; four patients presented with pain abdomen, fever and vomiting. On examination diffuse tenderness, guarding, rigidity was present. Two patients presented with mass in right iliac fossa with per rectal bleeding, and on PR examination red currant jelly was seen. All the 11 patients were subjected to routine investigations. X ray erect showed multiple air fluid levels in 5 patients, gas under diaphragm in 2 and X ray was inconclusive in 4 patients showing only dilated bowel loops. These 4 patients were subjected to USG abdomen. 2 had ileocolic intussusception and other 2 showed had pyoperitoneum.

All 11 cases were subjected for emergency exploratory laparotomy. Of them 5 cases had mesodiverticular band( fig-1a), in 4 of them release of band with diverticulectomy was done; in one patient necrosis of ileum was seen due to pressure necrosis by band hence segmental resection of ileum and anastomosis was done. In another two patients intussusception was seen in which segmental resection of ileum and anastomosis was done due to gangrene of ileum (fig-1b). 4 patients had perforated Meckel's diverticulum. In 2 patients perforation was on tip and a diverticulectomy was done (fig- 2a). In other two patients, perforation was on base and hence a segmental resection of ileum with anastomosis was also done (fig- $2 \mathrm{~b}$ ).

3 patients presented with chronic abdominal pain, 2 patients had associated bleeding PR. Abdominal USG showed enlarged and edematous Meckel's diverticulum with diverticulitis in one child, who had only pain abdomen. All showed positive tracer after subjecting to Meckel's TC 99 scan (fig- 2c). All three patients underwent diverticulectomy.

2 patients, one 1 month old and another 8 month presented with reddish umbilical swelling with greenish discharge (fig-3a). On examination reddish mucosa over umbilicus with 2 small openings with bilious discharge seen and was diagnosed as VI duct prolapsed (Meckel's prolapse). Umbilicus was cannulated with infant feeding tube and dye study was done, it showed dye communicating with small intestine (fig- $3 \mathrm{~b}$ ). Both case were underwent segmental resection of ileum and anastomosis. In another case incidentally Meckel's diverticulum was found as a content of right sided inguinal hernia (Littre's hernia). Since diverticulum had wide mouth, it was reduced and herniotomy was done (fig- 3c). The various presentations and clinical features are shown in TABLE 2.

COMPLICATIONS: Most common surgical complication seen post operatively was wound infection. In two cases of perforation, burst abdomen was seen and in both the cases tension suturing was done.

Early post-operative complications were pain, fever, vomiting, wound infection, paralytic ileus, burst abdomen. Incisional hernia was noted as delayed post-operative complication in one case. 
ORIGINAL ARTICLE

\begin{tabular}{|l|c|c|c|}
\hline Age in years & \multicolumn{2}{|c|}{ Sex } & Total no of cases \\
\hline & Male & female & \\
\hline 1month-1 yr. & 1 & 1 & 2 \\
\hline 1yr-4yr & 3 & 2 & 5 \\
\hline 5yr-14yr & 6 & 4 & 10 \\
\hline & 10 & 07 & 17 \\
\hline
\end{tabular}

TABLE 1: AGE AND SEX INCIDENCE

\begin{tabular}{|c|c|c|c|c|c|}
\hline SL NO & SYMPTOMS & $\begin{array}{c}\% \\
\text { percentage }\end{array}$ & $\begin{array}{c}\text { Pre-operative } \\
\text { diagnosis }\end{array}$ & $\begin{array}{l}\text { Operative } \\
\text { diagnosis }\end{array}$ & Type of surgery \\
\hline 1 & $\begin{array}{l}\text { Bilious vomiting, } \\
\text { abdominal } \\
\text { distension }\end{array}$ & $29.4 \%[5]$ & $\begin{array}{l}\text { Intestinal } \\
\text { obstruction }\end{array}$ & Meckel's Band & $\begin{array}{l}\text { Release of band \& } \\
\text { Diverticulectomy }\end{array}$ \\
\hline 2 & $\begin{array}{l}\text { F/o Intestinal } \\
\text { obstruction \&per } \\
\text { rectal bleed }\end{array}$ & $11.7 \%[2]$ & Intussusception & $\begin{array}{l}\text { Intussusception with } \\
\text { Meckel's as lead } \\
\text { point }\end{array}$ & $\begin{array}{l}\text { Diverticulectomy } \\
\text { Segmental resection of } \\
\text { ileum \& anastomosis }\end{array}$ \\
\hline 3 & $\begin{array}{l}\text { Vomiting } \\
\text { Abdominal } \\
\text { distension } \\
\text { Fever }\end{array}$ & $23.5 \%[4]$ & $\begin{array}{l}\text { Intestinal } \\
\text { perforation }\end{array}$ & $\begin{array}{l}\text { Perforated Meckel's } \\
\text { Diverticulum with } \\
\text { peritonitis }\end{array}$ & $\begin{array}{l}\text { Diverticulectomy } \\
\text { Segmental Resection of } \\
\text { ileum \& anastomosis }\end{array}$ \\
\hline 4 & Pain abdomen & $5.8 \%[1]$ & & Diverticulitis & Diverticulectomy \\
\hline 5 & $\begin{array}{l}\text { Bleeding per } \\
\text { rectum }\end{array}$ & $11.7 \%[2]$ & Diverticulitis & Diverticulitis & Diverticulectomy \\
\hline 6 & $\begin{array}{l}\text { Umbilical } \\
\text { discharge } \\
\text { Umbilical } \\
\text { swelling }\end{array}$ & $11.7 \%[2]$ & & $\begin{array}{l}\text { Prolapsed meckel's } \\
\text { diverticulum }\end{array}$ & $\begin{array}{l}\text { Diverticulectomy } \\
\text { Segmental Resection of } \\
\text { ileum \& anastomosis }\end{array}$ \\
\hline 7 & $\begin{array}{l}\text { Swelling in the } \\
\text { groin }\end{array}$ & $5.8 \%[1]$ & Inguinal hernia & Littre's hernia & Herniotomy \\
\hline
\end{tabular}

16 Meckel's diverticulum specimens were subjected to histopathology and table -3 shows the details. Ectopic gastric mucosa is the most common type.

\begin{tabular}{|l|c|c|}
\hline \multicolumn{1}{|c|}{ Mucosa type } & No of patients & percentage \\
\hline Gastric & 10 & $62.5 \%$ \\
\hline Pancreatic & 4 & $25 \%$ \\
\hline Gastric \&pancreatic & 2 & $12.5 \%$ \\
\hline \multicolumn{2}{|c|}{ Table 3: Histologic Types } \\
\hline \multicolumn{2}{|c|}{}
\end{tabular}




\section{ORIGINAL ARTICLE}

DISCUSSION: Though the first recorded observation of an ileal diverticulum has been attributed to Fabricius Hildamus in 1650, Littre reported its presence in a hernia in 1745 and Meckel first described its association with the omphalomesenteric duct. The omphalomesenteric duct connects the yolk sac to the intestinal tract during early fetal life. This structure is usually obliterated by the fifth to seventh week of gestation. ${ }^{1}$ Failure to regress may lead to several anomalies including omphalomesenteric fistula, umbilical sinus, umbilical cyst, or Meckel's Diverticulum. The Meckel's Diverticulum may be free (74\%) or attached (26\%) by fibrous bands to the umbilicus. ${ }^{3}$ Meckel's $^{2}$ Diverticulum is a congenital malformation of the small intestine, affecting about $2 \%$ of the population. Only 4 to $6 \%$ of Meckel's Diverticulum is known to be symptomatic and the presentations can be quite varied. The male to female ratio is reported as $2: 1$ to $4: 1 .^{4,6} \mathrm{In}$ our study male to female ratio is $1.4: 1$.

Various types of clinical presentations of Meckel's diverticulum signify more than one mechanism for production of these symptoms and signs. Curiously different presentations occur at different ages. Intestinal obstruction due to bands is the leading presentation all over the world, in all age groups with frequency ranging from $38 \%$ to $80 \%$. In our study intestinal obstruction was the most common presentation and was seen in $29.5 \%$ of the cases. ${ }^{7}$

Diagnosis and management of complicated or incidental Meckel's diverticulum in children has undergone significant changes in the minimal access era. The diagnosis of Meckel's diverticular complications, based on clinical features and conventional radiological modalities, is fraught with limitations as Meckel's diverticulum is a mobile structure and mimics other common conditions. Meckel's diverticular bleeding, the commonest presentation related to complicated Meckel's diverticulum, ranges from 1 to $10 \%$, but should be less in this modern era of early diagnosis and minimal invasive therapy. ${ }^{1}$

In diagnosis, the most precise test in childhood is scintigraphy with Tc99m pertechnetate (Meckel's scan). Other imaging methods such as ultrasonography, computed tomography, barium meal and angiography can rarely diagnose this condition. ${ }^{8}$ The prerequisite for the detection of the Meckel's Diverticulum by Tc99 sodium pertechnetate scintigraphy is the presence of ectopic gastric mucosa. The high affinity of this isotope for parietal cells of gastric mucosa permits visualization of both eutopic and ectopic gastric tissue. The residual isotope is concentrated in the urinary bladder. A positive scan shows abnormal uptake of the isotope outside the stomach and urinary bladder. The Meckel's scan has a reported sensitivity of 81 to $90 \% .{ }^{1,4}$ In our study Meckel's scan was done in only 3 patients because rest all patients presented either as a surgical emergency or diagnosis was obvious on clinical and radiological examination.

Artigas et al. $^{9}$ concluded that the presence of ectopic tissue in patients with the Meckel's Diverticulum seems to be the main risk for occurrence of an acute non-mechanical complication. Ectopic gastric tissue is found in 60 to $82 \%$, pancreatic in 1 to $16 \%$ and both in 5 to $12 \%$ of cases. Other less common tissues include colonic, duodenal and biliary. ${ }^{3}$ The definitive treatment for symptomatic Meckel's Diverticulum is surgery, which includes wedge resection, diverticulectomy and segmental ileal resection. Das PC et al from India reports 12 wedge resection/ diverticulectomies and 9 segmental ileal resections in his 21 case series. ${ }^{10}$ In our study of symptomatic cases, $46.9 \%$ underwent undergone diverticulectomy and $46.9 \%$ of the cases underwent segmental resection of ileum. Wound infection was a common complication. Reported mortality and morbidity for Meckel's Diverticulum are 6 to $7.5 \%$ and 6 to $30 \%$, respectively. No deaths were reported in our series. 
CONCLUSION: A Pre-operative diagnosis of complicated Meckel's Diverticulum may be challenging because of the overlapping clinical and imaging features of the other acute surgical and inflammatory conditions. An adequate knowledge of embryological, clinical, pathological and radiological characteristics of Meckel's diverticulum will aid in early diagnosis and treatment.

\section{REFERENCES:}

1. Blevrakis E, Partalis N, Seremeti C, Sakellaris G. Meckel's diverticulum in paediatric practice on Crete (Greece): A 10-year review. Afr J Paediatr Surg 2011; 8:279-82.

2. Maroof SA, Khan MJ, Khan Yousuf, UzairM. Surgical management of omphalomesenteric duct remnant in children. JPMI 2009; 23:179-83.

3. Moore GP, Burkle FM Jr. Isolated axial volvulus of a Meckel's diverticulum. Am J Emerg Med 1988; 6:137-42.

4. Menezes M, Tareen F, Saeed A, Khan N, Puri P. Symptomatic Meckel's diverticulum in children; A 16 year review. Paediatr Surg Int 2008;24:575-7.

5. Cooney DR, Duszynski DO, Camboa E, Karp MP, Jewett TC Jr. The abdominal technetium scan (a decade of experience). J Pediatr Surg 1982;17:611-9.

6. Yahchouchy EK, Marano AF, Etienne JF, Fingerhut AL. Meckel's diverticulum. J Am Coll Surg 2001;192:658-61.

7. Rehman I, Burki T, Alam S, Rahman F. Presentations of Meckel`s Diverticulum at Khyber Teaching Hospital Peshawar. J:Ayub Med CollAbottabad 2003;15:30-2.

8. Levy AD, Hobbs CM. Meckel diverticulum: Radiologic features with pathologic correlation. Radiographics 2004;24:565-87.

9. Artigas V, Calabuig R, Badia F, Rius X, Allende L, Jover J. Meckel's diverticulum: Value of ectopic tissue. Am J Surg 1986;151:631-4.

10. Cullen JJ, Kelly KA, Moir CR, Hodge DO, Zinsmeister AR, Melton LJ 3rd. Surgical management of Meckel's diverticulum: An epidemiologic, population-based study. Ann Surg 1994;220:564-9.

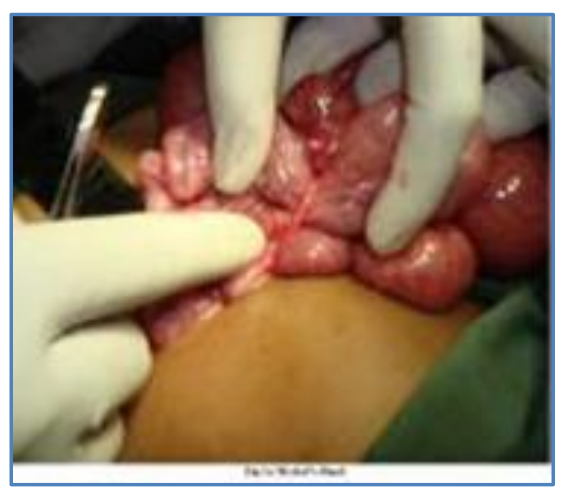

Fig. 1a: Meckel's Band

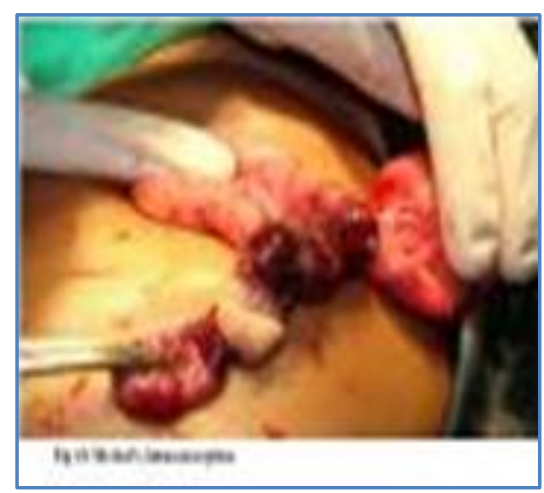

Fig. 1b: Meckel's Intussusception 


\section{ORIGINAL ARTICLE}

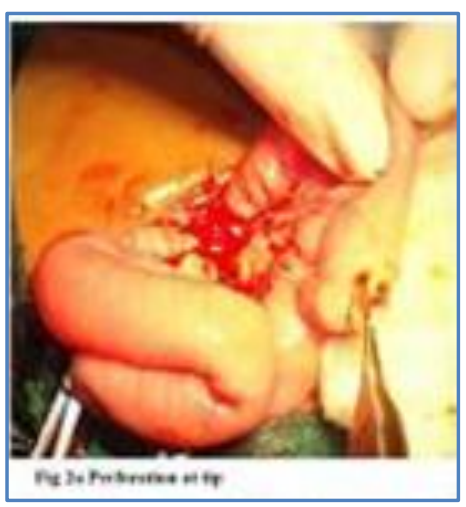

Fig. 2a: Perforation at tip

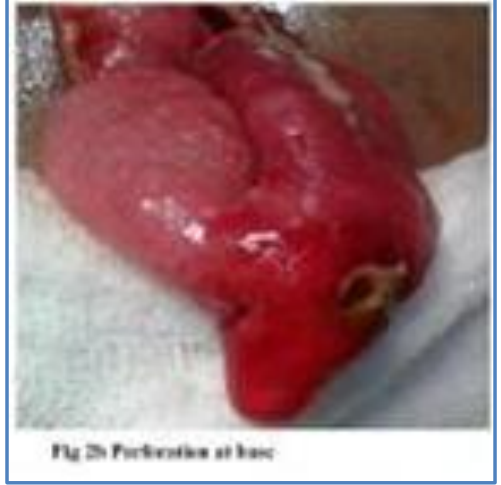

Fig. 2b: Perforation at base

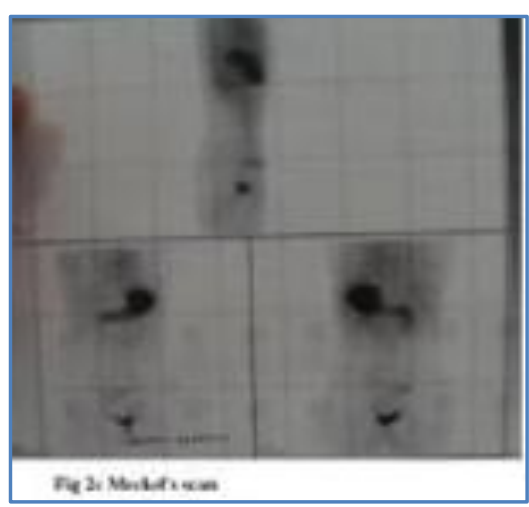

Fig. 2c: Meckel's Scan
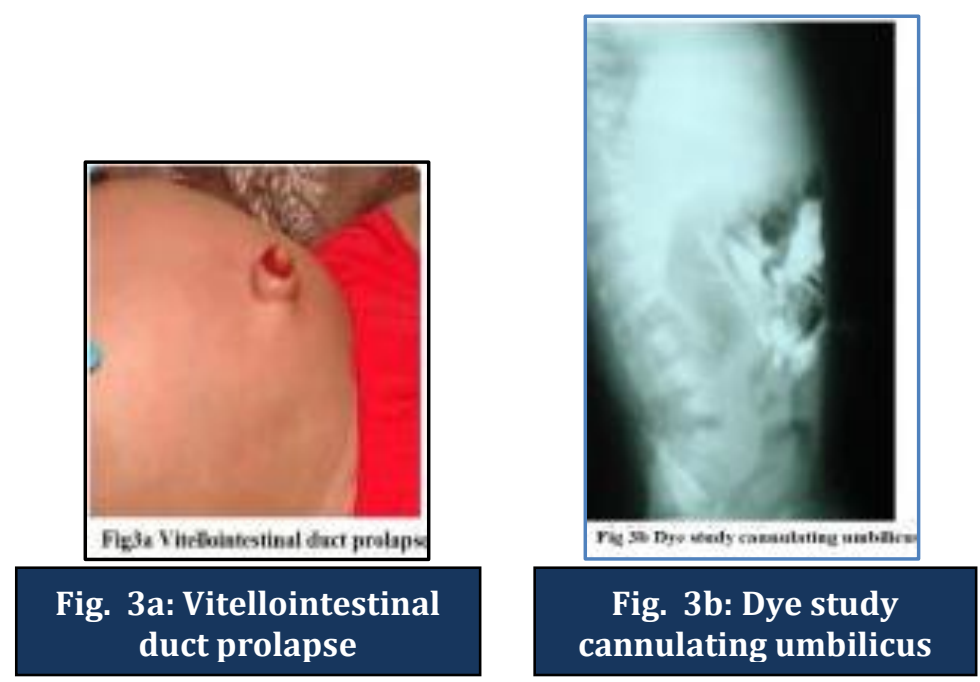

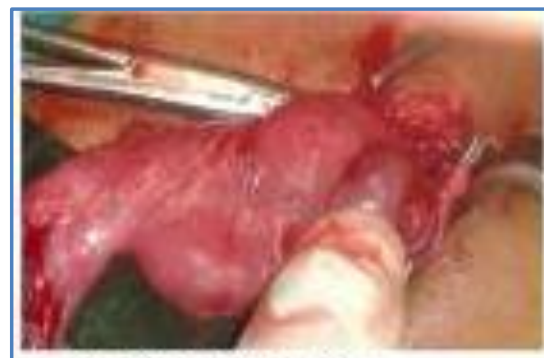

Fig 3e Littre's Hernia

Fig. 3c: Littre's hernia

\section{AUTHORS:}

1. Ramesh. B. Hatti

2. Mohammed. M. Pasha

\section{PARTICULARS OF CONTRIBUTORS:}

1. Assistant Professor, Department of Surgery, S. Nijalingappa Medical College and H. S. K Hospital, Bagalkot.

2. Post Graduate, Department of Surgery, S. Nijalingappa Medical College and H. S. K Hospital, Bagalkot.

\section{NAME ADDRESS EMAIL ID OF THE} CORRESPONDING AUTHOR:

Dr. Ramesh B. Hatti, Assistant Professor, Department of Surgery, S. N. M. C and H. S. K. Hospital, Navanagar, Bagalkot - 587102 .

E-mail:docrbh@gmail.com

Date of Submission: 30/01/2014.

Date of Peer Review: 31/01/2014.

Date of Acceptance: 08/02/2014.

Date of Publishing: 20/02/2014. 